\title{
CAMPYLOBACTERIOSIS: AN EMERGING ZOONOSIS, UNDERDIAGNOSED AND UNDERREPORTED BY PUBLIC HEALTH AGENCIES IN BRAZIL
}

\section{CAMPILOBACTERIOSE: UMA ZOONOSE EMERGENTE, SUBDIAGNOSTICADA E SUBNOTIFICADA PELOS ÓRGÃOS DE SAÚDE PÚBLICA NO BRASIL}

\author{
Eliane Pereira MENDONÇA ${ }^{1}$; Roberta Torres de MELO² ${ }^{2}$ Renata Resende PRADO ${ }^{3}$; \\ Guilherme Paz MONTEIRO ${ }^{4}$; Silvia Cassimiro BRASÃO ${ }^{5}$; Marcela Franco TIMOTEO ${ }^{6}$; \\ Daise Aparecida ROSSI ${ }^{7}$
}

1. Veterinary Doctor, Master's degree in Veterinary Science, PhD student in Veterinary Science - UFU, Uberlândia, MG, Brazil. eliane_vet@yahoo.com.br; 2. Biologist, Master's degree in Veterinary Science, PhD student in Veterinary Science - UFU, Uberlândia, MG, Brazil; 3. Veterinary Doctor, Student of master degree in Veterinary Science - UFU, Uberlândia, MG, Brazil; 4. Biologist, Master's degree in Veterinary Science - UFU, Uberlândia, MG, Brazil; 5. Veterinary Doctor, Student of master degree in Veterinary Science UFU, Uberlândia, MG, Brazil; 6. Veterinary Doctor, Student of master degree in Veterinary Science - UFU, Uberlândia, MG, Brazil; 7. Professor of the Faculty of Veterinary Medicine -UFU, Uberlândia, MG, Brazil.

\begin{abstract}
The infection by Campylobacter spp. constitutes a zoonosis of worldwide distribution, with serious repercussions for public health and a significant socio-economic impact. The Campylobacter species that most often are implicated in outbreaks of gastrointestinal disease are $C$. jejuni and $C$. coli. Both are recognized as the most important and with greater pathogenic potential from the viewpoint of food safety. This review aims to clarify and discuss, based on literature, the epidemiology of Campylobacter spp. and the main challenges in their control, to assist in better understanding of the risk posed to human health. Due to the difficulty of isolating and cultivating of Campylobacter spp., the high cost and not mandatory, laboratory diagnosis by traditional cultivation techniques is not widely used in Brazil, resulting in lack of accurate data on the occurrence of the disease in the country. This factor has been identified as responsible for underdiagnosing and underreporting of the disease, which means that data on contamination of animal products or outbreaks are not statements of actual national situation. The epidemiology of Campylobacter spp. is considered complex presenting multiple determinants in the spread of this microorganism. Chickens are important reservoirs of Campylobacter sp. and the main target of control measures, however, other vehicles of transmission, such as raw cow milk, drinking water and other foods of animal origin must also be considered in the set of measures to be taken to control disease. The infection by Campylobacter spp. cause gastroenteritis in humans and occurred by oral contact with infected animals. In fact, are pets or production and food consumption, the most important pathways. The clinical manifestations of the disease can be from mild to severe symptoms, including watery diarrhea, sometimes with blood, abdominal pain, fever, headache and nausea. Sometimes the infection can get complications after the diarrhea stops and starts a progressive paralysis that can result in respiratory failure and severe neurological dysfunction and may even lead to death. The occurrence of campylobacteriosi's outbreaks should be mandatory to the authorities of surveillance, to provide an investigation of common sources and transmission control through preventive measures, thereby minimizing the potential risks to human health.
\end{abstract}

KEYWORDS: Campylobacter spp.. Control. Broiler. Epidemiology. Brazil.

\section{INTRODUTION}

The infection by Campylobacter spp. is a zoonosis of worldwide distribution, with serious implications for public health and a significant socio-economic impact (EFSA, 2009). The high incidence of campylobacteriosis has become the most commonly cause of gastrointestinal disease reported worldwide (RIDLEY et al., 2008).

The reservoir of these organisms is the intestinal tract of domestic animals, wild or production (KELLER et al., 2007). Campylobacter species involved in human gastroenteritis are classified as thermo-tolerant by grow in temperatures higher than $40^{\circ} \mathrm{C}$, being the species $C$. jejuni, C. coli, C. lari and C. upsaliensis the most incriminated (NESBAKKEN et al., 2003).

C. jejuni is present in the intestinal tract of birds and mammals, including production and pet animals, being the cause of enteritis in young animals, including cattle, poultry, pigs, cats and dogs (GOMES, 2012) besides being the most prevalent species in human infections (RIDLEY et al., 2008).

Human infections occurs mainly by ingestion of raw or poorly processed poultry, pork and beef, or even by drinking unpasteurized milk and water, in addition to direct contact with carrier 
animals (FDA, 2012). From the Campylobacter species identified, the most implicated in outbreaks of gastrointestinal disease are C. jejuni and C. coli, being recognized as the most important and with greater pathogenic potential from the viewpoint of food safety (RIDLEY et al., 2008). C. upsaliensis is also considered an important cause of gastroenteritis in humans, but its true incidence is underestimated by conventional culture methods, because this species is inhibited by the antibiotics used in the culture medium for the isolation of other Campylobacter species (MURRAY et al., 2009).

The specie $C$. jejuni is the most common cause of gastroenteritis in the United States of America as C. coli accounts for $2 \%$ to $5 \%$ of cases. This last specie is the most common cause of gastroenteritis in developing countries (MURRAY et al., 2009).

Due to the difficulty of isolating and cultivating of Campylobacter sp., high cost and its monitoring not required by law in foods, the laboratory diagnosis is not widely used in Brazil. These facts have been identified as responsible for underdiagnoses and underreporting of the disease, which means that data about the contamination of animal products or outbreaks are not statements of the national situation. In contradiction to underreporting cases of campylobacteriosis in Brazil, in industrialized countries the cases of enteritis Campylobacter spp. are more frequent than those caused by Salmonella spp. (WHO, 2012).

In Brazil there is no specific legislation governing the analysis of Campylobacter spp., either by the Ministry of Agriculture, Livestock and Supply (Ministério da Agricultura, Pecuária e Abastecimento - MAPA) and the Ministry of Health (Ministério da Saúde) to expand the research in this area is needed to better analyze the occurrence of this pathogen in products of animal origin, as well as other foods that may be carriers of these agents and their potential risks to human health.

\section{DEVELOPMENT \\ Epidemiology}

The epidemiology of Campylobacter spp. is considered complex, and currently the actual incidence of infections by these organisms in Brazil is unknown, since the disease is not reported to official public health agencies. Some studies report that in developed countries, these bacteria cause gastroenteritis with a frequency of two to seven times greater than bacteria such as Escherichia coli O157:H7, Shigella spp. or even Salmonella spp. (ALLOS, 2001; WHO, 2012; EFSA, 2014).

The species $C$. jejuni and $C$. coli are recognized as the first agents of diarrhea in industrialized countries and second or third in developing ones, with transmission mainly associated with consumption of animal origin food (FERNÁNDEZ et al., 2005). The relevance of this fact is related to Campylobacter spp. presence in gastrointestinal tract of animals such as chickens and pigs, and their carcasses (JORGENSEN et al., 2002). This correlation arises from Campylobacter sp. colonization of these asymptomatically animals, this is the most important origin of carcasses contamination (BUHR et al., 2002).

The origin of $C$. jejuni presence in eggs is discussed, and little is known about the transmission. Researches show that the bacterium is restricted to the outside of egg shell (JONES et al., 2006; JONES; MUSGROVE, 2007). However, Campylobacter has been isolated in the internal contents of eggs that were negative on the outside (ADESIYUN et al., 2005). Thus, although studies shows that transmission is possible via transovarially (BUHR et al., 2002) this is not considered an important pathway in the spread of the pathogen and few studies show the passage of bacteria through the pores of the egg shell.

Fonseca et al. (2006) investigated the presence of Campylobacter sp. in matrices that were cloacal swabs positive for Campylobacter spp. using traditional microbiological culture and PCR techniques. The bacteria was detected by PCR, but not by traditional cultivation. Subsequently, Fonseca et al. (2011) placed the eggs in contact with contaminated shavings found that the bacteria were able to enter through the shell pores. They also observed that inoculation of $C$. jejuni outer of the egg membrane leads to high early embryonic mortality.

In a study conducted in Denmark meat samples were collected from slaughterhouses for Campylobacter spp. research, verifying that $47 \%$ of cattle, $46 \%$ of swine and $36 \%$ of chickens were contaminated by this pathogen. Another study conducted in the UK showed a prevalence of $32 \%$ for $C$. jejuni in feces samples collected from healthy dairy cows (YAN et al., 2005).

According to the EFSA (2009), the transmission of campylobacteriosis varies agreed with country development degree. Thus, in developing countries, the routes of transmission are complex and multifactorial and campylobacteriosis in developed countries is considered mainly a food infection whose main source is the chicken meat (EFSA, 2005). Murphy et al. (2006) states that the rate of campylobacteriosis incidence in the United States in 2004 was 12.9 cases per 100,000 
confirmed cases of food-borne bacterial diseases in humans, whereas in the UK the rate was 73/100.000 in 2003 and in the countries of northern Europe was 60 to $90 / 100.000$.

C. jejuni can survive and even multiply within free-living amoebae, establishing endosymbiotic relationships (OLOFSSON et al., 2013). This kind of symbiosis, between bacteria and protozoa, particularly Acanthamoeba castellanii, was also reported to Arcobacter butzleri, other species of family Campylobacteraceae (FERNÁNDEZ et al., 2012; MEDINA et al., 2014).

The fact that $C$. jejuni survives within freeliving amoebae, can have serious repercussions epidemiologically since these protozoa may act as reservoirs and / or vectors of bacteria that have the ability to survive as endosymbionts (KHAN, 2006). Furthermore, amoebas protect any microorganism that is inside of themselves, because they resist the action of disinfectants and adverse environmental conditions (KILVINGTON \& PRICE, 1990).

The possibility of companion animals, particularly dogs, could be a source of Campylobacter spp. which causes disease in humans has been investigated. Nowadays, there are epidemiological evidence of an association between Campylobacter spp. disease in dogs and in humans, however, are not clearly known the risk factors associated with this transmission (MSFFG, 2008). The frequency of Campylobacter species isolation that causes gastrointestinal diseases in Brazil is $9 \%$ in swine, $5 \%$ and $8 \%$ related to dogs and cats. In pigs, $C$. coli is the predominant specie. In dogs and cats, the highest rate of isolation is observed in individuals with less than six months old (AQUINO et al., 2002).

\section{Campylobacter in broiler carcasses}

The chickens are often colonized by $C$. jejuni (65 to 95\%) and less frequently by $C$. coli, and rarely by other Campylobacter spp. The colonization of broiler chickens is age related. The majority of birds is negative for the organism until two weeks of age, and once occurred colonization by Campylobacter spp. transmission by coprophagy is extremely fast and can be $100 \%$ of chickens' colonization over a 72 hours period (OIE, 2008).

The prevalence of Campylobacter $\mathrm{sp}$ in chickens and their carcasses is quite high, equivalent to $41.1 \%$ and $45.9 \%$ (BOTTELDOORN et al., 2008). A study carried out in Ireland, in 2008, showed that of 394 broiler cooled carcasses studied, 98\% were contaminated with C. jejuni (EFSA, 2010). In some European Union member countries in 2007 , the prevalence of fresh chicken meat was equivalent to $83 \%$. In Iran, the prevalence was $63 \%$ and in Japan 45.8\% (FAO, 2009). In Brazil, studies showed high prevalence of Campylobacter spp. Aquino et al. (2002) isolated C. jejuni and C. coli species in $60 \%$ of chicken carcasses samples analyzed and Kuana et al. (2008) in 99\% of the studied carcasses. Franchin et al. (2007) evaluated 335 carcasses samples, water and different points of the slaughter line equipment, and found positivity in $71.3 \%$ of samples. Lower rates were found by Melo (2012), who isolated Campylobacter spp. in $22.38 \%$ of 420 chicken chilled and frozen carcasses, from three Brazilian states (Minas Gerais, Goiás, Distrito Federal). Of these, $55(58.5 \%)$ were identify as $C$. jejuni, $19(20.2 \%)$ as $C$. coli and $20(21.3 \%)$ as Campylobacter spp.

According to Berrang et al. (2001), when a broiler flock contaminated with Campylobacter sp. enters the processing plant, it is likely that a large amount of the agent is already attached, or transferred to the skin during feathers withdrawal. The authors suggested that the increase in Campylobacter sp. chicken breast skin occurs at the time of feathers removal due to the elimination of the bacteria by the cloaca, which is facilitated by electric stunning of poultry. Campylobacter sp. has high survivability in extreme conditions during the production process of chickens due to the ability of attachment in the feathers follicles and the deep crevices of the bird skin. These recesses provide ideal conditions for bacteria to adhere to and support the variations in processing conditions (JANG et al., 2007). Therefore, it is able to survive in frozen meat $\left(-20^{\circ} \mathrm{C}\right)$ even after long periods, which makes this type of food a potential source of infection in case they are not properly cooked in the right temperature $\left(70-75^{\circ} \mathrm{C}\right.$ for 5 minutes) before consumption (MELO, 2013).

In Europe, the prevalence of Campylobacter sp. was $75.8 \%$ in broiler carcasses, which means that on average about eight out of 10 carcasses were contaminated. The most prevalent species were $C$. jejuni and $C$. coli, with $51.0 \%$ and $35.5 \%$, respectively. The proportion of negative samples quantitatively, in other words, below the threshold of $10 \mathrm{CFU} / \mathrm{g}$, ranged from $3.8 \%$ to $98.6 \%$ among European countries, while the proportion of samples with very high counts above $10,000 \mathrm{CFU} / \mathrm{g}$ ranged from $0 \%$ to $31.9 \%$ (EFSA, 2010). According to Yang et al. (2001) the incidence on carcasses is mainly affected by the process conditions of scalding and chiller.

The main locations in poultry colonization by Campylobacter spp., is the cecum, large intestine and cloaca (POTTURI-VENKATA et al., 2007). The 
high metabolic temperature of birds $\left(42^{\circ} \mathrm{C}\right)$ predisposes this species to be the main reservoir of Campylobacter spp. and assists in keeping this agent, since grow best in environments where temperatures around $42{ }^{\circ} \mathrm{C}$ (HORROCKS et al., 2008).

Stern and Ro Bach (2003) evaluated the presence of Campylobacter spp. in broiler carcasses in North Georgia, and compared the results obtained in 1995 and 2001, obtaining a lower bacterial count in the collections of 2001, which was attributed to the implementation of the Hazard Analysis System and Critical Control industry (HACCP ). They mentioned that among the factors that might have contributed to reducing contamination were the increasing of the volume of water used for housing (20L to $36 \mathrm{~L}$ ) and immersion in chiller containing 40 to $50 \mathrm{ppm}$ chlorine, procedures that were not performed in 1995.

The contamination of slaughter carcasses depends on several variables, including the age of the birds, the level of contamination of flocks and the influence of factors related to the production, transportation and processing. The level of contamination in these products has implications on public health and is fundamental to the existence of a traceability live birds in chicken carcasses in derivatives and sub-products (KUANA et al., 2008).

\section{Campylobacter in swine carcasses}

The epidemiology of infections caused by Campylobacter spp. in swine is complex, with multiple determinants in the spread of this microorganism. Along the chain production is possible to observe the expansion of the problem, usually by the rapid transmission of the bacteria to uninfected animals after contact with positive, animals and environments (GABRIEL, 2009).

Alter et al. (2005) could not isolate $C$. coli in swine after 24 hours of birth accommodated in the farm, but most animals $(75 \%)$ were colonized in the first week of life. The authors concluded that the incidence of $C$. coli increased from zero (newborns) to $78 \%$ (animals of 24 weeks) after transporting the animals from farm to slaughterhouse.

The occurrence and distribution of $C$. jejuni and $C$. coli was investigated by Jensen et al. (2006) in extensive swine farms in Denmark. The study showed high prevalence of Campylobacter spp. $(100 \%)$ in swine extensive creations, predominantly C. coli.

In Brazil, the prevalence of Campylobacter sp. in swine was evaluated in 120 feces samples and 120 swine carcasses from four different slaughterhouses in the state of São Paulo. Fecal samples from 30 (25\%) were positive for $C$. coli and two (1.6\%) for $C$. jejuni. All samples from carcasses (120) were negative for Campylobacter sp. (CAMPOS, 2006).

The effect of blast chilling (rapid cooling of the housing by contact with air at $21.9^{\circ} \mathrm{C}$ ) on the occurrence of Campylobacter sp. was evaluated by Nesbakken et al. (2007) in swine carcasses. The bacteria was isolated in $56.7 \%$ (34/60 lamb carcasses) before chilling and in $1.7 \%$ of the samples after the procedure. A significant decrease of these microorganisms in swine carcasses after chilling blast, and the authors attributed this effect to the sensitivity of the bacteria to freezing and drying.

The occurrence of Campylobacter sp. was investigated by Pearce et al. (2003) in a swine slaughterhouse. Thirty samples, representing 360 pig carcasses were evaluated. Campylobacter sp. was detected in $33 \%$ of samples after bleeding, $0 \%$ after scrap machine, $7 \%$ immediately before chilling, and $0 \%$ after all night at chilling. The bacteria was recovered in $100 \%$ of samples collected in the rectum and $80 \%$ of individual samples of the colon.

Prevalence and possible routes of Campylobacter spp. contamination in swine slaughterhouse were evaluated by Malakauskas et al. (2005) in Denmark. The study showed that 28/44 $(63.3 \%)$ samples collected at slaughter were contaminated by this bacteria, $23.4 \%$ of the isolates were identified as $C$. jejuni and $76.6 \%$ as $C$. coli. The results suggest that contamination was originated from the swine's gastrointestinal tract and happened during all the slaughter process.

Gabriel (2009) analyzed the presence of Campylobacter spp. in samples from swine finishing up the steps of slaughter from three batches (A, B and C), in the Triângulo Mineiro, Minas Gerais. Positivity in swine's feces housed at the farm was $66.6 \%, 53.3 \%$ and $80 \%$ in swine from the feedlots $\mathrm{A}, \mathrm{B}$ and $\mathrm{C}$, respectively. In meat samples collected from swine carcasses during slaughter results of positivity were $51.1 \%, 31.1 \%$ and $48.8 \%$, in flocks A, B and C, respectively. The same study also showed a higher rate of carcasses contamination after scalding step and scrap machine, with $57.7 \%$, which is believed to be the largest possible contamination of carcasses due to the characteristics of the process and difficulty of cleaning the equipment. Despite reported decrease in the number of positive samples during the slaughtering process steps studied were not able to guarantee the food safety.

Wilson et al. (2008) indicated for control of meat contamination by animal feces, equipment 
sterilization and additional care when handling the animals with positivity. The authors believe that the primary route of Campylobacter spp. transmission to humans is the food chain and suggests that the incidence can be dramatically reduced by improved of biosafety in farms and preventing transmission via food.

\section{Campylobacter in cattle}

Cattle and sheep, as swines, are also often colonized by Campylobacter spp. and colonization is higher in young than in older animals. In the older animals, the microorganisms are occasionally detected in feces, probably due to low levels then the possible elimination or intermittent excretion. These animals are primarily colonized by $C$. jejuni, C. coli, $C$. fetus and $C$. hyointestinalis, unlike swine that are predominantly colonized by $C$. coli (OIE, 2008). Several studies have reported that $C$. jejuni can cause enteritis in calves and bovine mastitis while $C$. fetus is responsible for abortion and infertility in cattle (STANLEY; JONES, 2003). $C$. fetus does not belong to the thermophilic species group.

Inglis et al. (2003) analyzed 380 fecal samples from feedlot cattle in Canada and found that $49 \%$ had C. lanienae. In the same study, $37 \%$ of samples were positive for $C$. jejuni, $8 \%$ to $C$. hyointestinalis and $0.5 \%$ for $C$. coli. Fernández and Hitschfeld (2009) analyzed 300 samples of fecal swabs of cows in Chile and obtained $32.0 \%$ positive for Campylobacter sp., with 85 identified as $C$. jejuni and 11 C. coli. Bailey et al. (2003) studied 19 flocks in Australia, and found that Campylobacter sp. prevalence varied from $0 \%$ to $24 \%$ for dairy cattle, and from $0 \%$ to $52 \%$ for cattle.

In Brazil, there is low information about the relevance of beef for $C$. jejuni and $C$. coli transmission transmission to humans; studies are needed to determine the prevalence of these bacteria in bovine products, as well as determining control measures (FERNÁNDEZ; HITSCHFELD, 2009). In ground beef meat analyzed by Ferreira (2008), the presence of Campylobacter sp. was detected in $32.5 \%(13 / 40)$ of samples.

The higher prevalence of Campylobacter sp. in beef cattle is an epidemiological event that can be associated with the environment in which these animals are housed. While these animals are raised on pasture and in contact with a diverse environment, dairy cattle are kept in confinement and in better hygiene conditions (FERNÁNDEZ; HITSCHFELD, 2009). In this sense, there is need to perform further studies to elucidate the sources of environmental contamination of beef. Furthermore, the environment of processing plants for these animals and the assessment of the food of bovine origin are also important factors in the implementation of specific control measures to improve the safety of the final product (FERNÁNDEZ; HITSCHFELD, 2009).

\section{Campylobacter in dogs}

According to Hirsh (2003) approximately $10 \%$ and $5 \%$ of asymptomatic dogs and cats are intestinal carriers of $C$. jejuni. These percentages may be higher in animals purchased in kennels. Prevalence of thermophilic Campylobacter species in samples of rectal swabs from dogs and cats varied with age group, with or without sign of gastroenteritis in two animal shelters in Ireland, showed that the isolation rate was higher in dogs and cats less than six months and significantly higher in dogs compared to cats (ACKE et al., 2006). Tenkate and Stafflord (2001) stated that about $6 \%$ of cases of human campylobacteriosis were transmitted from pets.

Knowing if living with pets increases the chances of human Campylobacter sp. infection is an epidemiological information that should be further investigated. This possibility warns of hygiene required in handling them and in order to avoid the promiscuity, mainly with children under five years, which is considered the highest risk group.

Rodrigues (2011) examined 120 feces samples from pets animals (103 dogs and 17 cats) attended at the Veterinary Hospital of the Faculty of Veterinary Medicine of Universidade Federal de Uberlândia. Of these 22/120 (18.3\%) were positive for Campylobacter spp. (20 dogs and two cats).There is an association between the presence of $C$. jejuni and diarrhea in animals. In addition to C. jejuni in asymptomatic animals, Rodrigues (2011) also identified C. coli.

\section{Campylobacter in humans}

Most cases of human campylobacteriosis are presented in isolated episodes, but outbreaks are also observed. Gastroentiritis infectious caused by Campylobacter spp. occurs in humans by oral via, through consumption of contaminated food of animal origin or by contact with pets or production infected. It can also occur by consumption of other foods such as unpasteurized milk or contaminated water (Figure 1). How not to feed via transmission can still quote the direct transmission from individual to individual, but is not considered an important mode of transmission in industrialized countries (EFSA, 2005). 


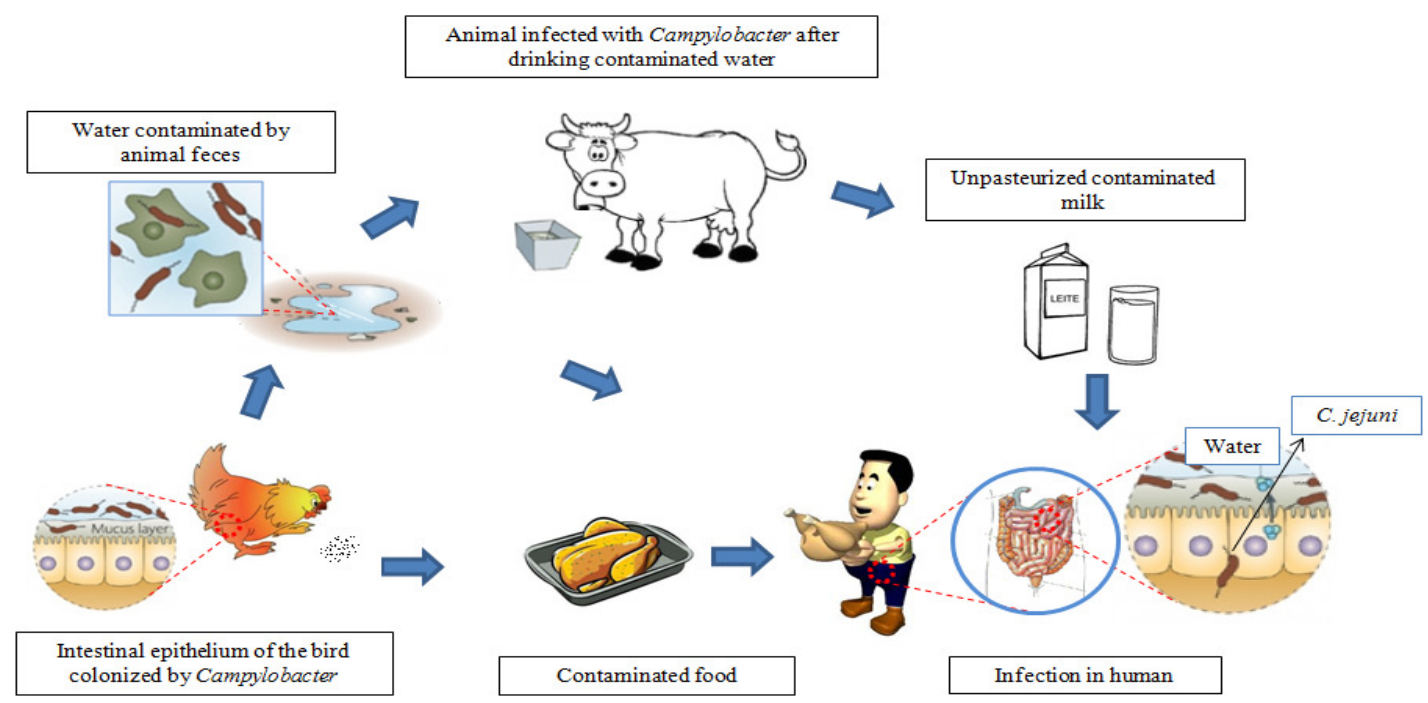

Figure 1. Leading transmission forms of Campylobacter spp. in animals and man. Figure adapted from Young et al. (2007).

C. jejuni is responsible for $80-90 \%$ of infections in humans, while $C$. coli is observed in $7 \%$ and $C$. lari, C. upsaliensis, and $C$. hyointestinalis only $1 \%$ of human cases (NESBAKKEN et al., 2003).

According Malakauskas et al. (2005), in Denmark, the number of registered cases of campylobacteriosis increased by four times with 82 infections per 100,000 inhabitants in 2002 , with the same trend observed in other industrialized countries. Reiersen et al. (2002) reported that in Iceland, the incidence of Campylobacter sp. in humans reached epidemic proportions between June 1998 and March 2000. Between 1990 and 1995, the incidence was 14.6 cases per 100,000 individuals/year. Since 1996, cases began to increase reaching 157 cases per 100,000 individuals in 1999. During 2000 and 2001, there was a fall (87.1 and 75.4 cases per 100,000 individuals, respectively).

In 2007, campylobacteriosis was the most frequently reported zoonotic disease in humans in the European Union with 200,507 confirmed cases and most states still points increase this number (EFSA, 2009).

In Chile, Fernández et al. (2005) serotyped 50 C. jejuni strains subsp. jejuni isolated from chicken carcasses and 50 isolated from children's feces, finding 17 different serotypes and 6 identical. The number of different serotypes suggests that in Chile's southern, not only the poultry meat is the vehicle of $C$. jejuni subsp. jejuni in humans, but other unidentified sources or reservoirs are involved.

There is a resistance to infection by Campylobacter spp. in individuals with eating habits high risk who are exposed to the agent several times, as occurs in developing countries. In a study conducted in Egypt, that is an endemic country to campylobacteriosis, residents are repeatedly exposed, this resulted in high rates of diarrhea and large production of antibodies against multiple serotypes of Campylobacter sp. in patients, especially in children (WIERZBA et al., 2008).

Rodrigues (2011) examined 160 feces samples from children attended at the Emergency Department of the Hospital of the Universidade Federal de Uberlândia, finding that $6.87 \%$ (11/160) samples were positive for Campylobacter spp. In feces of children with diarrhea, C. jejuni and C. coli were identified and in non-diarrheal feces, were identified as Campylobacter spp.

\section{Pathogenesis and virulence}

The infective dose of Campylobacter sp. is low, it is estimated that the intake of less than 500 cells can cause disease (IVANOVIC, 2012). The effort to define the role of specific virulence factors in diseases caused by Campylobacter sp. factors has been frustrated by the lack of an animal model to reproduce the disease. It is known that the primary mechanism of pathogenicity is the invasion of the intestinal mucosa which $C$. jejuni being the best studied species. Although adhesins, cytotoxic enzymes and enterotoxins have been detected in these species, its exact role in disease remains poorly defined, it became clear that the risk or severity of the disease to the host is influenced by the infecting dose and the immune status of the individual (MURRAY et al., 2009).

Bacteria of this genus are actively moving by a single polar flagellum at one or both ends of 
the cell. Variants of $C$. jejuni, properties with incomplete or no scourge can not colonize or require large amounts of inoculum, compared to mobile strains (complete flagellum), suggesting that the motility, has fundamental importance in colonization (GOMES, 2012).

According Jawets et al. (1998), species of Campylobacter sp. have lipopolysaccharides (LPS) and flagella structures that act as adhesion and invasion being able to produce cytotoxins and enterotoxins. Diverse microorganisms can multiply in the small intestine epithelium and then, the bacteria invade and cause inflammation, resulting in the appearance of erythrocytes and leukocytes in the feces. Eventually, the bloodstream is invaded by the bacteria and develop an enteric fever notes. The localized tissue invasion associated with toxic activity appears to be responsible for enteritis.

Having successfully fixation and internalization, Campylobacter spp. colonizes the epithelial cells by a number of mechanisms that include: invasion (RUSSEL et al., 1993), toxin production (WHITEHOUSE et al., 1998) and apoptosis (RUSSEL et al., 1993). In this environment, Campylobacter spp. can avoid the attack by phagocytes and enter the circulatory system in immunocompromised patients (WALLIS, 1994). The attack may involve phagocytosis by macrophages, release of intermediate reactions and release of inflammatory cytokine (JONES et al., 1999).

The flaA, ciaB, cadF and pldA genes are classified as reference for the study of the mechanisms of Campylobacter $s p$. pathogenicity (ZHENG et al., 2006). These genes encode proteins involved in adhesion and invasiveness of $C$. jejuni and can therefore be considered as possible virulence factors in this species. The flaA gene encoding flagellin $\mathrm{A}$, which is required for the adhesion and invasion of epithelial cells by $C$. jejuni (WASSENAAR et al., 1991), The ciaB gene encodes a protein involved in cell invasion (RIVERA AMILL et al., 2001), while $c a d F$ encodes a protein that interacts with fibronectin in the extracellular matrix of the host colonization participating cell surface (MONTEVILLE et al., 2003). The pldA gene is related to cellular invasion and encodes a protein involved in the synthesis of outer membrane phospholipase (ZIPRIN et al., 2001).

Melo et al. (2013) analyzed virulence genes in $C$. jejuni strains isolated from poultry carcasses in Brazil showing that this species has great importance in the pathogenesis of human disease. This work showed that flaA, pldA, cadA, ciaB and $c d t A B C$ genes involved in adhesion, colonization, invasion of cells and toxin production process, were present in $74.5 \%, 63.6 \%, 67.3 \%, 67.3 \%$ and $65.5 \%$ of the strains, respectively.

Several studies have reported the presence of these genes in C. jejuni strains isolated from humans regardless of the source and the ability of adhesion and invasion in Caco-2 cells (ZHENG et al., 2006).

Besides these, the extensional citolethal toxin has been linked to the pathogenesis of $C$. jejuni in human and animal infections (DATTA et al., 2003). This toxin affects the layer of epithelial cells, causing progressive distension and death in various cell lineages by the intracellular accumulation of cyclic adenosine mono-phosphate (cAMP) (MARTINEZ et al., 2006).

As invasive bacteria, Campylobacter sp. can lead to septicemia. The treatment of patients with sepsis by Campylobacter sp. must be intense given that the prognosis is unfavorable. Related extraintestinal Campylobacter sp. infections like meningitis diseases are considered rare. Some postinfection manifestations may occur, such as reactive arthritis, urticaria or erythema nodosum and Guillain-Barré Syndrome (GBS), which, is the most severe manifestation (ALVES, 2006).

It has been recognized association between campylobacteriosis and GBS. The disease is usually of acute evolution, lasting hours or days, with rapidly progressive weakness, sometimes progressing to respiratory failure, but with good recovery. In more severe cases, respiratory failure may occur, leading to cardiac arrhythmias, sweating and hypertensive peaks, with a mortality rate between $4 \%$ and $10 \%$ of cases (CANAL; PÁEZ, 2007).

Godschalk et al. (2004) determined that specific bacterial genes, known as lipooligosaccharides of $C$. jejuni (LOS) genes are required for the biosynthesis of ganglioside mimic structures of the nervous tissue and induction of anti-gangliosides antibodies. This molecular mimicry of $C$. jejuni (LOS) with gangliosides is considered an inducer of cross-reactive antibodies that lead to GBS.

Gastroenteritis by $C$. jejuni characteristically produces histological lesions of the mucous surfaces of the jejunum, ileum and colon. The mucosa appears edematous, ulcerated and bloody, with abscesses in the crypts of epithelial glands and infiltration of the lamina by neutrophils, mononuclear cells and eosinophils. This inflammatory infiltrate is characteristic of invasion of microorganisms in the intestinal tissue 
(MURRAY et al., 2009).

The ability of invasion seems to be strain dependent and strains isolated from the environment are much less invasive in HeLa cells than strains isolated from humans or animals (EVEREST et al., 1993). Melo et al. (2013) selected five strains classified as most virulent to verify its ability to alter the morphology of Caco- 2 cells and observed a loss of cells confluence for all strains tested. This loss of cellular integrity, reflected by loss of the ability to transport fluids and electrolytes between cells, contributes to the clinical symptoms of campylobacteriosis in vivo.

As already discussed, the main risk factor for human infection includes ingestion and handling of poultry, mainly chicken, raw or improperly processed, accounting for $50 \%$ to $70 \%$ of campylobacteriosi's cases (SERNIENE; MALAKAUSKAS, 2008). Food contamination can occur in all of the food chain, directly or indirectly by cross-contamination, meaning a major risk to human health (ELLIS-IVERSEN et al., 2009).

\section{Clinical signs}

The clinical manifestations, when they occur, involve human and younger animals (FONSECA, 2006). Chickens and pigs are asymptomatic carriers of Campylobacter sp., but there may be clinical signs in lambs and sheep (abortion and metritis by $C$. jejuni), dogs and cats (diarrhea and frequent vomiting by $C$. jejuni and $C$. upsaliensis) (PARK, 2002).

According to the World Health Organization (WHO, 2011) Campylobacter sp. in human is the leading cause of severe forms of diarrhea. The incubation period ranges from two to five days, reaching up to 10 days (ALVES, 2006; GARCÍA; CRAVIOTO, 2007). Before the onset of symptoms, usually 12-24 hours, it is usual that presents a period with fever, headache and general malaise. At the beginning of infection, fecal matter is aqueous, but insofar as the disease progresses, it becomes bloody. The presentation can vary from a lighter form of short-term to a more severe and prolonged framework (CANAL; PÁEZ, 2007).

Infection rarely results in consequences that remain long-term in order to develop more serious diseases such as sepsis, abortion, meningitis, abscesses and complications such as GBS. GBS is an autoimmune disease that causes widespread flaccid paralysis annually and may affect up to four people for every 100,000 inhabitants. Approximately $60 \%$ to $70 \%$ of patients with GBS have any acute illness of one to three weeks before symptoms appear, the infection being the most common $C$. jejuni. This syndrome has a variant known as the Miller-Fisher syndrome, characterized by ataxia, areflexia and ophthalmoplegia (BRAZIL, 2009).

When $C$. jejuni invades the human body, the immune response activates the production of antibodies specific against to LOS. However, the cell membrane of human nerve cells contains compounds with exactly the same molecular structure that LOS. Thus, LOS structure mimics the structure of ganglioside, and antibodies produced in response to $C$. jejuni also react against nerve cell membrane. The result is nerve damage that occurs in characteristic paralysis of GBS (MURRAY, 2007).

Another syndrome resulting from infection by $C$. jejuni is Reiter's syndrome or reactive arthritis. This syndrome is an autoimmune response that causes inflammation (arthritis) in various joints in response to infection by $C$. jejuni. It is more common in large weight-bearing joints such as the knees and lower back, but other joints may also be affected (MURRAY et al., 2007).

The symptomatology presented by campylobacteriosis includes aqueous, moderate and self-limiting diarrhea, until dysentery with blood, mucus and white blood cells, and may be accompanied by headache and abdominal pain, fever, malaise, nausea and vomiting.

The acute phase lasts for up to three days of diarrhea and abdominal pain may persist for up to three weeks. Recovery is rapid, usually a week. Antibiotic treatment is recommended only in severe casesnand when other underlaying clinical conditions exist. Rest and fluid therapy are shown to reverse the symptoms of this disease, which in most cases is self-limiting.

Death as a result of campylobacteriosis is rare but can happen when there is widespread disease in immunocompromised individuals or in very young or elderly patients. Study reveals that the case fatality rate of infections by Campylobacter spp. is in the range of 0.05 cases per 1,000 infections in humans (ALLOS, 2001).

\section{Treatment}

The antimicrobial agents of choice are erythromycin, clarithromycin or azithromycin, which are able to reduce and eliminate the microorganism in the feces. A clinical improvement is observed if treatment is started before the third day of the onset of symptoms (CAMPDERÁ et al., 2007).

Studies in children with diarrhea caused by C. jejuni, showed a rapid improvement using an early treatment with erythromycin. Clinical 
experience and controlled studies demonstrated that treatment with antibiotics is prudent in patients with high fever, bloody stools and diarrhea with more than eight evacuations per day (GARCÍA; CRAVIOTO, 2007).

Although no clinical efficacy trials have been conducted in animals, it was reported that erythromycin (which is the drug of choice in humans) in doses from 11.1 to $15.5 \mathrm{mg} / \mathrm{kg}$, orally, three times daily for seven days, eliminated the infection in dogs and cats (HOLT, 1994).

The resistance of Campylobacter to antimicrobials commonly used is a current issue that is under discussion both in the context of veterinary and human medicine. The occurrence of strains resistant to multiple antibiotics, including that of choice for treatment in humans limits the therapeutic options.

According to the CDC (2013) the rates of antibiotic resistance in microorganisms isolated from humans, especially to fluoroquinolones, have risen sharply in the past 20 years, and these high rates of resistance are seen today in many regions of the world. For the treatment of campylobacteriosis, in adults, the drug of first choice are those belonging to the class of fluoroquinolones (CDC, 2013). When the resistance to this drug is proven, azithromycin (macrolide) is generally the next choice of treatment, although resistance to this class of antimicrobials has also already been reported (CDC, 2013).

Since campylobacteriosis is transmitted by consumption of food, the role of the indiscriminate use of these antibiotics in the different stages of the production chain of chickens can promote the spread of resistant strains. Various reports around the world associate Campylobacter sp. infections resistant to fluoroquinolones with the approval of the use of this antimicrobial in poultry production (SERICHANTALERGS et al., 2007).

Rastall (2004) investigated alternative antibiotics sources for campylobacteriosis treatment and found that the use of a probiotic (Lactobacillus acidophilus) together with a prebiotic (fructooligosaccharides, and lactosucrose) showed positive effects on the balance of intestinal microflora, an there was an improvement in recovery from infection and immune status. This balance of microflora occurs by competitive exclusion of pathogens after the use of probiotics (RINKINEN, 2003).

\section{Control and Prevention}

The control of human Campylobacter sp. infections should begin with actions to reduce infection rates in animal reservoirs used for food production, and consequently, the danger of their presence in food of animal origin. During the slaughter, sanitary practices should be implemented to prevent cross-contamination, and proper sanitation of equipment, facilities and tools.

At home and restaurants, enteric campylobacteriosis can be prevented by an appropriated preparation of food, particularly poultry preparation, avoiding consumption of unpasteurized dairy products and implementing measures to prevent contamination of water supplies. Moreover, one should prevent crosscontamination during food preparation (GONÇALVES et al., 2012).

Since Campylobacter spp. are sensitive to heat, the consumption of properly cooked poultry meat seems to be a good measure of control to prevent infection by the bacteria (ALLOS, 2001).

The transmission of pet disease to man is a pathway for the spread of infection. Human cases are associated with diarrheic dogs and cats recently acquired. The veterinarian should advise the owner of the infected practicing appropriate hygiene measures as an animal: perform a thorough hand washing after contact with animals, promote the proper disposal of contaminated feces, cleaning in place where animals deposit their feces and separate infected animals babies and children until the cultures after treatment confirm that the infection has cleared (ETTINGER, 1992).

\section{CONCLUSIONS}

Outbreaks or human cases of campylobacteriosis require immediate notification to the authorities of local, regional or central surveillance, for which initiate the investigation of common sources and transmission control through preventive measures (banning contaminated products, among other educational measures).

Special attention should be given to monitoring the contamination of chicken meat, to be involved in most cases of human campylobacteriosis. Despite the great Brazilian chicken meat production and the prominent position that the country occupies on the world stage, data on the Campylobacter sp. incidence in poultry in Brazil are still scarce, mainly due to the absence of national surveillance programs.

It is important that the analysis of Campylobacter sp. in foods is established and regulated by the relevant authorities. Knowledge of the prevalence of these organisms in Brazil will allow checking the danger they pose to consumers. 
Studies available to date indicate that the control measures to prevent human campylobacteriosis should be undertaken throughout the chain production of animal origin food, from animals rearing to food preparation in homes.

RESUMO: A infecção por Campylobacter spp. constitui em uma zoonose de distribuição mundial, com graves repercussões em saúde pública e com um impacto sócio-econômico significativo. Das espécies de Campylobacter sp., as que estão mais frequentemente implicadas nos surtos de doença gastrointestinal são $C$. jejuni e $C$. coli, sendo reconhecidas como as mais importantes e com maior potencial patogênico do ponto de vista da segurança alimentar. Esta revisão visa esclarecer e discutir, com base nos dados da literatura, a epidemiologia de Campylobacter sp. e os principais desafios no seu controle, para auxiliar no melhor entendimento do risco que representa para a saúde humana. Devido à dificuldade de isolamento e cultivo de Campylobacter sp., ao alto custo da análise e da mesma não ser obrigatória, o diagnóstico laboratorial por meio de técnicas tradicionais de cultivo não é muito utilizado no Brasil, acarretando falta de dados precisos sobre a ocorrência da doença no país. Este fator tem sido identificado como responsável por subdiagnóstico e subnotificação da enfermidade, o que significa que dados sobre contaminação de produtos de origem animal ou surtos não são demonstrativos da real situação nacional. A epidemiologia das infecções por Campylobacter spp. é considerada complexa, apresentando múltiplos fatores determinantes na disseminação desse microrganismo. As aves são importantes reservatórios de Campylobacter sp. e o principal alvo de medidas de controle, porém, outros veículos de transmissão, como o leite cru, a água potável e outros alimentos de origem animal também precisam ser considerados no conjunto de medidas a serem adotadas para o controle da doença. A infecção por Campylobacter sp. causadoras de gastroenterite no homem acontece principalmente por via oral, mas pode ocorrer também pelo contato com animais de estimação ou de produção infectados. O quadro clínico da doença varia desde sintomas leves a graves, incluindo diarreia aquosa, algumas vezes com sangue, dor abdominal, febre, dor de cabeça e náuseas. Porém, pode haver complicações posteriores devido resposta auto-imune levando a paralisia progressiva que pode resultar em insuficiência respiratória e disfunção neurológica grave, podendo até mesmo levar a morte. A ocorrência de casos ou surtos de campilobacteriose devem ser notificados às autoridades de vigilância epidemiológica, para que se desencadeie a investigação das fontes comuns e o controle da transmissão por meio de medidas preventivas, minimizando assim os potenciais riscos para a saúde humana.

PALAVRAS-CHAVE: Campylobacter spp.. Controle. Frango de Corte. Epidemiologia. Brasil

\section{REFERENCES}

ACKE, E.; WHYTE, P.; JONES, B. R.; McGILL, K.; COLLINS, J. D.; FANNING, S. Prevalence of thermophilic Campylobacter species in cats and dogs in two animal shelters in Ireland. Veterinary Record, London, v. 158, p. 51-54, 2006. http://dx.doi.org/10.1136/vr.158.2.51

ADESIYUN, A.; OFFIAH, N.; SEEPERSADSINGH, N.; RODRIGO, S.; LASHLEY, V.; MUSAI, L.; GEORGES, K. Microbial health risk posed by table eggs in Trinidad. Epidemiology and Infection, Cambridge, v. 133, p. 1049-1056, 2005. http://dx.doi.org/10.1017/S0950268805004565

ALLOS, B. M. Campylobacter jejuni infections: update on emerging issues and trends. Clinical Infectious Diseases, Chicago, v 32, p. 1201-1206, 2001. http://dx.doi.org/10.1086/319760

ALTER, T.; GAULL, F.; KASIMIR, S.; GURLER, M.; MIELKE, H.; LINNEBUR, M. Prevalences and transmission routs of Campylobacter spp. strains within multiple pig farms. Veterinary Microbiology, Leipzig, v. 108, p. 251-261, 2005. http://dx.doi.org/10.1016/j.vetmic.2005.03.004

ALVES, E. Scientific News - Camylobacter. Informativo Cefar de Microbiologia. Year III, Ed 16, 2006. Available in: < http://www.cefar.com.br/download/jornal\%2016ed_web.pdf>. Accesses: feb $05^{\text {th }} 2013$.

AQUINO, M. H. C.; PACHECO, A. P. G.; FERREIRA, M. C. S.; TIBANA, A. Frequency of isolation and Identification of Thermophilic Campylobacters from Animals in Brazil. The Veterinary Journal, London, v. 164, p. 159-161, 2002. http://dx.doi.org/10.1053/tvj1.2001.0698

BAILEY, G. D.; VANSELOW, B .A.; HORNITZK, M. A.; HUM, S. I.; EAMENS, G. J.; GILL, P. A.; KEITH, H.; WALKER, K. H.; CRONIN, J. P. A study of the foodborne pathogens: Campylobacter, Listeria and 
Yersinia, in faeces from slaughter-age cattle and sheep in Australia. Communicable diseases intelligence quarterly report, v. 20, p. 249-256, 2003.

BERRANG, M. E.; BUHR, R. J.; CASON, J. A.; DICKENS, J. A. Broiler carcass contamination with Campylobacter from feces during defeathering. Journal of Food Protection, Des Moines, v. 64, p. 2063-2066, 2001.

BOTTELDOORN, N., VAN COILLIE, E., PIESSENS, V. RASSCHAERT, G., DEBRUYNE, L., HEYNDRICKX, M., HERMAN, L.; MESSENS, W. Quantification of Campylobacter spp. in chicken carcass rinse by real-time PCR. Journal of Applied Microbiology, Oxford, v. 105, p.1909-1918, 2008. http://dx.doi.org/10.1111/j.1365-2672.2008.03943.x

BRASIL, MINISTÉRIO DA SAÚDE. Protocola Clínico e Diretrizes Terapêutica. Síndrome de GuillainBarré. Portaria SAS/MS nº 497, de 23 de dezembro de 2009.

BUHR, R. J.; COX, N. A.; STERN, N. J.; MUSGROVE, M. T.; WILSON, J. L.; HIETT, K. L. Recovery of Campylobacter from segments of the reproductive tract of broiler breeder hens. Avian Diseases, Kennett Square, v. 46, p. 919-924, 2002.

CAMPDERÁ, G A. J.: FERNANDEZ, R. R.; SANCHEZ. M. I. G.. Gastroenteritis por Salmonella, Shigella y Campylobacter. 2007. Available in: < http://www.aeped.es/protocolos/infectologia.pdf $>$. Accessed: dec. $12^{\text {th }}$, 2012.

CAMPOS, F. R. Isolamento e caracterização de Campylobacter spp. em amostras de fezes e carcaças de suínos provenientes de abatedouros do Estado de São Paulo. 2006. 47 f. Dissertation (Master) - Faculdade de Medicina Veterinária e Zootecnia, Universidade de São Paulo, São Paulo, 2006.

CANAL, V. A.; PÁEZ F. S. Estudio para la implementacion del analisis de Campylobacter spp según la metodologia USDA/FSIS MLG capitulo 61998 em el laboratório Labser de Rancagua Chile. 2007. 62 f. Facultad de Ciencias Carrera de Microbiologia Industrial, Pontifica Universidad Javeriana, Rancagua, 2007.

CDC (Centers For Disease Control and Prevention). Travelers' Health. In: Mahon, B.E. Chapter 3: Infectious Diseases Related To Travel: Campylobacteriosis. 2013. Available in: < http://wwwnc.cdc.gov/travel/yellowbook/2014/chapter-3-infectious-diseases-related-totravel/campylobacteriosis. Accessed: mar. $25^{\text {th }}, 2014$.

DATTA, S.; NIWA, H.; ITOH, K. Prevalence of 11 pathogenic genes of Campylobacter jejuni by PCR in strains isolated from humans, poultry meat and broiler and bovine faeces. Journal of Medical Microbiology, London, v. 52, n. 4, p. 345-348, 2003. http://dx.doi.org/10.1099/jmm.0.05056-0

EFSA - EUROPEAN FOOD SAFETY AUTHORITY. Analysis of the baseline survey on the prevalence of Campylobacter in broiler batches and of Campylobacter and Salmonella on broiler carcasses in the EU, 2008. The EFSA Journal, Italy, v. 8, n. 3, p. 1503, 2010.

EFSA - EUROPEAN FOOD SAFETY AUTHORITY; ECDC - EUROPEAN CENTRE FOR DISEASE PREVENTION AND CONTROL. 2014. The European Union Summary Report on Trends and Sources of Zoonoses, Zoonotic Agents and Food-borne Outbreaks in 2012. The EFSA Journal, Italy, v. 12, n. 2, p. 3547, 312 pp, 2014.

EFSA - EUROPEAN FOOD SAFETY AUTHORITY. Opinion of the scientiphic panel on biological hazards on the request from the Commission related to Campylobacter in animals and foodstuffs. The EFSA Journal, Italy, v. 173, p. 1-10. 2005. Available in: <http://www.efsa.europa.eu/EFSA/efsa_locale1178620753812_1178620776955.htm>. Accessed: jan. 28 2013. 
EFSA - EUROPEAN FOOD SAFETY AUTHORITY. The Community Summary Report on Trends and Sources of Zoonoses and Zoonotic Agents in the European Union in 2007. The EFSA Journal, Italy, v 223, p. 109-134, 2009. Available in: <http://www.efsa.europa.eu/EFSA/efsa_locale1178620753812_1211902269834.htm>. Accesses: dec. 14 $4^{\text {th }}, 2012$.

ELLIS-IVERSEN, J.; PRITCHARD, G.; WOOLDRIDGE, M.; NIELEN, M. Risk Factors for Campylobacter jejuni and Campylobacter coli in young cattle on English and Welsh farms. Preventive Veterinary Medicine, Amsterdam, v. 88, p. 42-48, 2009. http://dx.doi.org/10.1016/j.prevetmed.2008.07.002

ETTINGER, S. J. Infecções bacterianas do trato intestinal. In: Tratado de medicina interna veterinária: molésias do cão e do gato. Tradução de Sônia de Aguiar Gomes do Nascimento e Fernando Gomes do Nascimento. 3. Ed. São Paulo: Manole, 1992, p. 280.

EVEREST, P. H.; GOOSSENS, H.; BUTZLER, J. P.; LLOYD, D.; KNUTTON, S.; KETLEY, J. M.; WILLIAMS, P. H. Differentiated Caco-2 cells as a model for enteric invasion by Campylobacter jejuni and $C$. Colli. Journal of Medical Microbiology, London, v. 37, p. 319-325, 1993. http://dx.doi.org/10.1099/00222615-37-5-319

FAO/WHO. Risk assessment of Campylobacter spp. in broiler chickens: Technical Report. Microbiological Risk Assessment Series No. 12. Geneva. 132pp. 2009.

FERNÁNDEZ, H.; GARCÍA, A.; VILLANUEVA, M. P. Serotipos de Campylobacter jejuni ssp, jejuni aislado de aves para consumo humano y en muestras de heces de niños com diarrea. Archivos de Médicina Veterinaria, Valdivia, Chile, v. 37, p. 79-81, 2005.

FERNÁNDEZ, H.; HITSCHFELD, M. Occurrence of Campylobacter jejuni and Campylobacter coli and their biotypes in beef and dairy cattle from the south of Chile. Brazilian Journal of Microbiology, São paulo, v. 40, p. 450-454, 2009.

FERNÁNDEZ, H., M. P. Villanueva, G. Medina. 2012. Endosymbiosis of Arcobacter butzleri in Acanthamoeba castellanii. Revista Argentina de Microbiologia, Buenos Aires, v. 44, p. 133

FERREIRA, I. M. Riscos relacionados à contaminação microbiana de carne moída bovina. 2008. 62 f. Dissertation (Master) - Programa de Pós Graduação em Ciências Veterinárias da Faculdade de Medicina Veterinária, Universidade Federal de Uberlândia, Uberlândia, 2008.

FONSECA, B. B.; BELETTI, M. E. ; MELO, R. T. ; MENDONCA, E. P. ; LEVENHAGEM, M. A. ; UEIRAVIEIRA, C. ; ROSSI, D. A. Transfer, viability and colonisation of Campylobacter jejuni in the chicken vitellus and in embryos. British Poultry Science (Print), London, v. 52, p. 279-286, 2011.

FONSECA, B. B. Transmissão vertical de Campylobacter sp em um sistema de produção avícola. 2006. 65 f. Dissertation (Master) - Programa de Pós Graduação em Ciências Veterinárias da Faculdade de Medicina Veterinária, Universidade Federal de Uberlândia, Uberlândia, 2006.

FOOD AND DRUG ADMINISTRATION - FDA. Bad Bug Book, Foodborne Pathogenic Microorganisms and Natural Toxins. 2. Ed. 2012. Available in: < http://www.fda.gov/downloads/food/foodborneillnesscontaminants/ucm297627.pdf >. Accessed: feb. 01 ${ }^{\text {st }}$, 2014.

FRANCHIN, P. R.; OGLIARI, P. J.; BATISTA, C. R. V. Frequency of thermophilic Campylobacter in broiler chickens during industrial processing in a Southern Brazil slaughterhouse. British Poultry Science, London, v. 48, p. 127-132, 2007. http://dx.doi.org/10.1080/00071660701261286 
GABRIEL, M. R. Campylobacter spp. na cadeia produtiva da suínos. 2009. 66 f. Dissertation (Master) Programa de Pós Graduação em Ciências Veterinárias da Faculdade de Medicina Veterinária, Universidade Federal de Uberlândia, Uberlândia, 2009.

GARCÍA, C. E.; CRAVIOTO, Q. A. Campylobacter y enfermedades asociadas. Revista da Faculdade de Medicina UNAM, México, v. 50, n. 1, p. 31-35, 2007.

GODSCHALK, P. C.; HEIKEMA, A. P.; GILBERT, M.; KOMAGAMINE, T.; ANG, C. W.; GLERUM, J.; BROCHU, D.; LI, J.; YUKI, N.; JACOBS, B. C.; VAN BELKUM, A.; Endtz, H. P. The crucial role of Campylobacter jejuni genes in anti-ganglioside antibody induction in Guillain-Barré syndrome, Journal of Clinical Investigation, New York, v. 114, n. 11, p. 1659-1665, 2004. http://dx.doi.org/10.1172/JCI200415707

GOMES, M. J. P. Gênero Campylobacter spp. Porto Alegre: UFRGS, 2012. 45 p. Workboock. Available in: <http://www.ufrgs.br/labacvet/files/Gênero Campylo 4-2012-2.pdf>. Accessed: jan. $12^{\text {th }}, 2013$.

GONÇALVES, K. O.; YAMANAKA, E. H. U.; ALMEIDA, A. P. I.; CHANO, L. J.; RIBEIRO, A. B. Pesquisa de Campylobacter spp. em carnes de frango comercializados na cidade de Campo Mourão-PR. Alimentos e Nutrição, Marilia, v. 23, n. 2, p. 211-216, 2012.

HIRSH, D. C. Organismos espiralados I: Campylobacter - Arcobacter - Lawsonia (Trato Digestivo). In: HIRSH, D. C.; CHUNG ZEE, Y. Microbiologia Veterinária. 2. Ed. Rio de Janeiro: Guanabara Koogan, 2003 p. 83-86.

HOLT, J. G. Bergey's Manual of determinative Bacteriology. 9. Ed. Baltimore: Williams e Wilkins, 1994.

HORROCKS, S. M., ANDERSON, R. C., NISBET, D. J.; RICKE, S. C. Incidence and ecology of Campylobacter jejuni and coli in animals. Anaerobe, Ames, v xxx, p. 1-8, 2008.

INGLIS, G. D.; KALISCHUK, L. D.; BUSZ, H. A survey of Campylobacter species shed in faeces of beef cattle using polymerase chain reaction. Canadian Journal of Microbiology, Ottawa, v. 49, p. 655-661, 2003. http://dx.doi.org/10.1139/w03-087

IVANOVIC, S. Campylobacter as a cause of gastroenteritis in humans and animals. African Journal of Microbiology Research, v. 6, n. 8. p. 1651-1657, 2012.

JANG, K. I.; KIM, M. G.; HA, S. D.; LEE, K. A.; CHUNG, D. H., KIM, C. H., KIM, K. Y. Morphology and adhesion of Campylobacter jejuni to chicken skin under varying conditions. Journal of Microbiology and Biotechnology, Oxford, v. 17, n. 2, p. 202-206, 2007.

JAWETS, E.; MELNICK, J. L.; ADELBERG, E. A. Vibrio, Campylobacter and Helicobacter bacteria associated. In: Microbiologia Médica. 20. Ed. Rio de Janeiro: Guanabara, 1998.

JENSEN, A. N.; DALSGAARD, A.; BAGGESEN, D. L.; NIELSEN, E. M. The ocurrence and characterization of Campylobacter jejuni and C. coli in organic pigs and their outdoor environment. Veterinary Microbiology, Denmark, v. 116, p. 96- 105, 2006. http://dx.doi.org/10.1016/j.vetmic.2006.03.006

JONES, D. R.; MUSGROVE, M. T.; CAUDILL, A. B.; CUTRIS, P. A. Frequency of Salmonella, Campylobacter, Listeria and Enterobacteriaceae detection in commercially cool water-washed shell eggs. Journal of Food Safety, Westport, Conn., v. 26, p. 264-274, 2006.

JONES, D. R.; MUSGROVE, M. T. Pathogen prevalence and microbial levels associated with restricted shell eggs. Journal of Food Protection, Des Moines, v. 70, p. 2004-2007, 2007. http://dx.doi.org/10.1111/j.17454565.2006.00048.x 
JONES, S. L.; LINDBERG, F. P.; BROWN, E. J. Phagocytosis. In: PAUL, W. E. (Ed.). Fundamental immunology. 4 ed. Philadelphia: Lippincott-Raven, 1999 p. 1011-1015.

JORGENSEN, F.; BAILEY, R.; WILLIAMS, S.; HENDERSON, D. R. Prevalence and numbers of Salmonella and Campylobacter spp. on raw, whole chickens in relation to sampling methods. International Journal of Food Microbiology, Amsterdam, v. 76, p. 151-164, 2002. http://dx.doi.org/10.1016/S0168-1605(02)00027-2

KELLER, J.; WIELAND, B.; WITTWER, M.; STEPHAN, R.; PERRETEN, V. Distribution and genetic variability among Campylobacter spp. isolates from different animal species and humans in Switzerland. Zoonoses Public Health, Berlin, v. 54, p. 2-7, 2007. http://dx.doi.org/10.1111/j.1863-2378.2007.00981.x

KHAN, N.A. 2006. Acanthamoeba: biology and increasing importance in human health. FEMS Microbiology Reviews. Amsterdam, v. 30, p. 564-595. http://dx.doi.org/10.1111/j.1574-6976.2006.00023.x

KILVINGTON, S.; J. Price. 1990. Survival of Legionella pneumophila within cysts of Acanthamoeba polyphaga following chlorine exposure. Journal of Applied Bacteriology, Oxford, v. 68, p. 519-525. http://dx.doi.org/10.1111/j.1365-2672.1990.tb02904.x

KUANA, S. L.; SANTOS, L. R.; RODRIGUES, L. B.; A. BORSOI, A.; MORAES, H. L. S.; SALLE, C. T. P.; NASCIMENTO, V. P. Occurrence And Characterization Of Campylobacter In the Brazilian Production and Processing Of Broilers. Avian Diseases Digest, Jacksonville, v. 3, p. 27, 2008. http://dx.doi.org/10.1637/19335334-3.4.e27

MALAKAUSKAS, M.; JORGENSEN, K., NIELSEN, E.M., OJENIYI, B., OLSEN, J.E. Isolation of Campylobacter spp. from a pig slaughterhouse and analysis of cross contamination. International Journal of Food Microbiology, Copenhagen, v. 108, n. 3, p. 295-300, 2005.

MARTINEZ, I.; MATEO, E.; CHURRUCA, E.; GIRBAU, C.; ALONSO, R.; FERNANDEZASTORGA, A. Detection of cdtA, cdtB, and cdtC genes in Campylobacter jejuni by multiplex PCR. International Journal of Medical Microbiology, Jena, v. 296, n. 1, p. 45-48, 2006. http://dx.doi.org/10.1016/j.ijmm.2005.08.003

MEDINA, G., Flores-Martin, S., Fonseca, B., Otth, C., Fernández, H., 2014. Mechanisms associated with phagocytosis of Arcobacter butzleri by Acanthamoeba castellanii. Parasitology Research, Berlin, v. 113, n. 5, p. 1933-1942, 2014. http://dx.doi.org/10.1007/s00436-014-3842-8

MELO, R. T. Fatores de Patogeniciade e Potencial Risco à Saúde em Campylobacter spp. Isolados de Carcaças de Frangos. 2012. 134 f. Dissertation (Master) - Programa de Pós Graduação em Ciências Veterinárias da Faculdade de Medicina Veterinária, Universidade Federal de Uberlândia, Uberlândia, 2012. http://dx.doi.org/10.1016/j.foodcont.2013.02.032

MELO, R. T.; NALEVAIKO, P. C.; MENDONÇA, E. P.; BORGES, L. W.; FONSECA, B. B.; BELETTI, M. E.; ROSSI, D. A. Campylobacter jejuni strains isolated from chicken meat harbour several virulence factors and represent a potential risk to humans. Food Control, Guildford, v. 33, p. 227-231, 2013.

MONTEVILLE, M. R.; YOON, J. E.; KONKEL, M. E. Maximal adherence and invasion of INT 407 cells by Campylobacter jejuni requires the $C a d F$ outer membrane protein and microfilament reorganization.

Microbiology, Reading, v. 149, n. 1, p. 153-165, 2003. http://dx.doi.org/10.1099/mic.0.25820-0

MSFFG - MICROBIOLOGICAL SAFETY OF FOOD FUNDERS GROUP. (2008). UK publicy funded research relating to Campylobacter: update 2007. Available in: <

http://www.food.gov.uk/multimedia/pdfs/Campylobacter2.PDF >. Accessed: jan. 10 $0^{\text {th }}, 2013$.

MURPHY, C.; CARROLL, C.; JORDAN, K. N. Environmental survival mechanisms of the foodborne pathogen Campylobacter jejuni. Journal of Applied Microbiology, Oxford, v. 100, p. 623-632, 2006. http://dx.doi.org/10.1111/j.1365-2672.2006.02903.x 
MURRAY, P. R.; BARON, E. J.; JORGENSEN, J.H.; LANDRY M. L.; PFALLER, M. A. Manual of Clinical Microbiology. 9. Ed. Washington, 2007.

MURRAY, P. R.; ROSENTHAL, K. S.; PFALLER, M. A. Campylobacter e Helicobacter. In: Microbiologia médica. 6. Ed. Rio de Janeiro: Elsevier. Capítulo 32, p. 321-328, 2009.

NESBAKKEN, T.; ECKNER, K.; HOIDAL, H. K.; ROTTERUD, O. J. Occurrence of Yersinia enterocolitica and Campylobacter spp. in slaughter pigs and consequences for meat inspection, slaughtering, and dressing procedures. International Journal of Food Microbiology, Amsterdam, v. 80, p. 231-240, 2003. http://dx.doi.org/10.1016/S0168-1605(02)00165-4

NESBAKKEN, T.; ECKNER, K.; ROTTERUD, O. J. The effect of blast chilling on occurrence of human pathogenic Iersinia enterocolitica compared to Campylobacter spp. and numbers of hygienic indicators on pig carcasses. International Journal of Food Microbiology, Oslo, v. 123, p. 130-133, 2007.

http://dx.doi.org/10.1016/j.ijfoodmicro.2007.12.011

OIE - OFFICE INTERNATIONAL DES EPIZOOTIES. Campylobacter jejuni and Campylobacter coli. In OIE Terrestrial Manual 2008. Chapter 2.9.3., p. 1185-1191, 2008.

OLOFSSON, J., Axelsson-Olsson. D, Brudin. L, Olsen. B, Ellström. P. 2013. Campylobacter jejuni actively invades the amoeba Acanthamoeba polyphaga and survives within non digestive vacuoles. PLOS One, Cambridge, v. 8, n. 11, 2013.

PARK S. F. and ELVERS K. T. Quorum sensing in Campylobacter jejuni: detection of a luxS encoded signaling molecule. Microbiology, United Kingdom, v. 148, p, 1475-1481, 2002.

PEARCE, R. A.; WALLACE, F. M.; CALL, J. E.; DUDLEY, R. L.; OSER, A.; YODER, L.; SHERIDAM, J. J.; LUCHANSKY, J. B. Prevalence of Campylobacter within a swine slaughter and processing facility. Journal of Food Protection, Des Moines, v. 66, p. 1550-1556, 2003.

POTTURI-VENKATA, L. P., BACKERT, S., LASTOVICA, A. J., VIEIRA, S. L., NORTON, R. A., MILLER, R. S., PIERCE, S.; OYARZABAL, O. A. Evaluation of different plate media for direct cultivation of Campylobacter species from live broilers. Poultry Science, Champaign, III., v. 86, p. 1304- 1311, 2007.

RASTALL, R. A. Bacteria in the gut: friends and foes and how to alter the balance. The Journal of Nutrition, Philadelphia, v. 134, p. 2022-2026, 2004.

REIERSEN, J.; BRIEM, H.; HARDARDOTTIR, H.; GUNNARSSON, E.; GEORGSSON, F.;

GUDMUNDSDOTTIR, E.; KRISTINSSON, K. G. Human Campylobacteriosis epidemic in Iceland 1998-2000 and effect of interventions aimed at poultry and humans. Marrakech: FAO/WHO Global Forum of Food Safet Regulators. 2002.

RIDLEY, A. M.; TOSZEGERY, M. J.; CAWTHRAW, S. A.; WASSENAAR, T. M.; NEWELL, D. G. Genetic instability is associated with changes in the colonization potential of Campylobacter jejuni in the avian intestine. Journal of Applied Microbiology, Oxford, v. 105, n. 1, p. 95-104, 2008.

http://dx.doi.org/10.1111/j.1365-2672.2008.03759.x

RINKINEN, M.; JALAVA, K.; WESTERMARCK, E.; SALMINEN, S.; OUWEHAND, A.C. Interaction between probiotic lactic acid bacteria and canine enteric pathogens: a risk factor for intestinal Enterococcus faecium colonization?. Veterinary Microbiology, Amsterdam, v. 92, p. 111-119, 2003. http://dx.doi.org/10.1016/S0378-1135(02)00356-5

RIVERA-AMILL, V.; KIM, B. J.; SESHU, J.; KONKEL, M. E. Secretion of the virulence associated Campylobacter invasion antigens from Campylobacter jejuni requires a stimulatory signal. Journal of Infectious Diseases, Chicago, v. 183, n. 11, p. 1607-1616, 2001. http://dx.doi.org/10.1086/320704 
RODRIGUES, C. G Ocorrência e suscetibilidade antimicrobiana de Campylobacter spp. em cães, gatos, crianças e sua importância zoonótica. 2011. 63 f. Dissertatation (Master) - Programa de Pós Graduação em Ciências Veterinárias da Faculdade de Medicina Veterinária, Universidade Federal de Uberlândia, Uberlândia, 2011.

RUSSEL, R. G.; O’KONNOGHUE, M.; BLAKE, D.C.; ZULTY, J.; DeTOLLA, L. J. Early colonic demaage and invasion of Campylobacter jejuni in experimentally challenged infant Macaca Mulatta. The Journal of Infectious Disease, Oxford, v. 168, p. 210-215, 1993. http://dx.doi.org/10.1093/infdis/168.1.210

SERICHANTALERGS, O.; DALSGAARD, A.; BODHIDATTA, L.; KRASAESUB, S.; PITARANGSI, C.; SRIJAN, A.; MASON, C. J. Emerging fluoroquinolone and macrolide resistance of Campylobacter jejuni and Campylobacter coli isolates and their serotypes in Thai children from 1991 to 2000. Epidemiology and Infection, Cambridge, v. 135, n. 8, p. 1299-1306, 2007. http://dx.doi.org/10.1017/s0950268807008096

SERNIENE, L.; MALAKAUSKAS, M., KUDIRKIENE, E., MALAKAUSKAS, A. Isolation and identification of thermophilic Campylobacter spp. by PCR-RFLP in broilers flocks. Veterinarija Ir Zootechnika, v. 42, n. 64, p. 44-47, 2008.

STANLEY, K.; JONES, K. Cattle and sheep farms as reservoirs of Campylobacter. Journal of Applied Microbiology, Oxford, v. 94, p. 104S-113S, 2003. http://dx.doi.org/10.1046/j.1365-2672.94.s1.12.x

STERN, N. J.; RO BACH, M. C. Enumeration of Campylobacter spp. in broiler feces and in corresponding carcasses. Journal of Food Protection, Des Moines, v. 66, p. 1557-1563, 2003.

TENKATE, T. D.; STAFFORD, R. J. Risk factors for campylobacter infection in infants and young children: a matched case-control study. Bulletin of Entomological Research, Farnham Royal, v. 127, p. 399-404, 2001. http://dx.doi.org/10.1017/s0950268801006306

WALLIS, M. R. The pathogenesis of Campylobacter jejuni. British Journal of Biomedical Science, London, v. 51, p. 54-64, 1994.

WASSENAAR, T. M.; BLEUMINK-PLUYM, N. M.; VAN DER ZEIJST, B. A. M. Inactivation of Campylobacter jejuni flagellin genes by homologous recombination demonstrates that flaA but not flaB is required for invasion. The EMBO journal, Oxford, v. 10, n. 8, p. 2055-206, 1991.

WHITEHOUSE, C. A.; BALBO, P. B.; PESCI, E. C.; COTTLE, D. L.; MIRABITO, P. M.; PICKETT, C. L. Campylobacter jejuni cytolethal distending toxin causes a G2-phase cell cycle block. Infection and immunity, Washington, v. 66, p. 1934-1990, 1998.

WIERZBA, T. F.; MESSIH, I. A.; GHARIB, B.; BAQAR, S.; HENDAUI, A.; KHALIL, I.; OMAR, T. A.; KHAYAT, H. E.; PUTNAM, S. D.; SANDERS, J. W.; NG, L. K.; PRICE, L. J.; SCOTT, D. A.; FRENCK, R. R. Campylobacter infection as a tregger for Guillain-Barré Syndrome in Egypt. Central Journals Plos One, v. 3, p. E.3664, 2008. Available in: < http://www.pubmedcentral.nih.gov.picrender.fcgi >. Accessed: feb. $08^{\text {th }}, 2010$.

WILSON, D. J.; GABRIEL, E.; LEATHERBARROW, A. J. H.; CHEESBROUGH, J.; GEE, S.; BOLTON, E.; FOX, A.; FEARNHEAD, P.; HART, C. A.; DIGGLE, P. J. Tracing the source of campylobacteriosis. Plos Genetics, Cambridge, v. 4, n. 9, 2008.

WORLD HEALTH ORGANIZATION - WHO . The global view of campylobacteriosis. 2012. Available in: $<$ https://extranet.who.int/iris/restricted/bitstream/10665/80751/1/9789241564601_eng.pdf > Accesses: mar. 27 ${ }^{\text {th }}$, 2014.

WORLD HEALTH ORGANIZATION- WHO. Water-related diseases. 2011. Available in: $<$ http://www.who.int/water_sanitation_health/diseases/campylobacteriosis/en/> Accessed: aug. $23^{\text {th }}, 2011$. 
YANG , H.; LI, Y.; JOHNSON, M. G. Survival and death of Salmonella Typhimurium and Campylobacter jejuni in processing water and on chicken skin during poultry scalding and chilling. Journal of Food Protection, Des moines, v. 64, p. 770-776, 2001.

YAN, S.; PENDRAK, M.; FOLEY, S.; POWERS, J. Campylobacter infection and Guillain-Barré syndrome: public health concerns from a microbial food safety perspective. Clinical and Applied Immunology Reviews, v. 5, p. 285-305, 2005. http://dx.doi.org/10.1016/j.cair.2005.08.001

YOUNG, K. T.; DAVIS, L. M.; DIRITA, V. J. Campylobacter jejuni: molecular biology and pathogenesis. Nature Reviews Microbiology, v. 5, p. 665-679, 2007. http://dx.doi.org/10.1038/nrmicro1718

ZHENG, J.; MENG, J. H.; ZHAO, S. H.; SINGH, R.; SONG, W. X. Adherence to and invasion of human intestinal epithelial cells by Campylobacter jejuni and Campylobacter coli isolates from retail meat products. Journal of Food Protection, Des Moines, v. 69, n. 4, p. 768-774, 2006.

ZIPRIN, R. L.; YOUNG, C. R.; BYRD, J. A.; STANKER, L. H.; HUME, M. E.; GRAY, S. A.; KIM, B. J.; KONKEL, M. E. Role of Campylobacter jejuni potential virulence genes in cecal colonization. Avian Diseases, kennett Square, v. 45, n. 3, p. 549-557, 2001. 